\title{
Spora Katılım Motivasyonu: Görme Engelli Sporcular Üzerine Bir Araştırma
}

\author{
Gönül TEKKURŞUN DEMIR ${ }^{1 *}$ (D) $\quad$ Ekrem Levent ILHAN ${ }^{1}$ (D) \\ ${ }^{1}$ Gazi Üniversitesi, Spor Bilimleri Fakültesi, ANKARA
}

Orijinal Makale / Original Article

Geliş Tarihi / Received: 11.02.2019 Kabul Tarihi / Accepted: 18.03.2019ＹＹayın Tarihi / Published: 22.03.2019

\begin{abstract}
Öz
Görme engelliler genel bir ifade ile görme yetersizliğinden etkilenen kişilerdir. Görme engelli bireylerin gündelik yaşam içinde yerini alması, sosyalleşerek hayata bağlanması, hedefine motivasyonla yönelmesi, görme engelliliğinin yaşama devam etmek için bir engel olmadığı fikrinin kabullenilmesine yardımcı olan önemli unsurlardan biri spordur. Bu araştırmada lisanslı görme engelli sporcuların spora katıım motivasyon düzeylerinin çeşitli değişkenlere göre belirlenmesi amaçlanmıştır. Bu bağlamda araştırmada nicel araştırma yöntemlerinden betimsel tarama modeli kullanıımışıı. Araşıımaya Türkiye Görme Engelliler Spor Federasyonu'ndan toplam 80 lisansı sporcu katılmıştı. Araştırmada veri toplama aracı olarak araştırmacılar tarafından hazırlanan kişisel bilgi formu ile Tekkurşun, IIlhan, Esentürk ve Kan (2018) tarafından geliştirilen "Engelli Bireylerde Spora Katılım Motivasyonu Ölçeği (ESKMÖ)" kullanılmıştır. Araştırmada elde edilen verilerin analizinde; frekans, aritmetik ortalama, standart sapma; Pearson Moment Korelasyon Testi, Mann-Whitney U ve Kruskal-Wallis testleri kullanılmıştır. Araştırmada, görme engelli joducuların içsel motivasyon puan ortalamalarının haltercilerden; dışsal motivasyon puan ortalamalarının ise goalballcilerden anlamlı düzeyde yüksek olduğu saptanmıştır. Sporcuların yaşı ile lçsel Motivasyon düzeyi arasında pozitif yönde orta düzeyde anlamlı farklılık tespit edilmiştir. Katılımcıların cinsiyetine göre anlamlı farkılıı saptanmamışıı. Görme engelli sporcuların spor yaşı ile İçsel Motivasyon, Dışsal Motivasyon ve Motivasyonsuzluk boyutları arasında pozitif yönde yüksek düzeyde anlamlı farklılık saptanmışıır. Görme engelli sporcuların spora katılım motivasyonlarının yüksek düzeyde olduğu sonucuna varılmıştır.

Anahtar Kelimeler: Engelli, Görme Engelli, Spor, Spora Katılım Motivasyonu, Motivasyon
\end{abstract}

\footnotetext{
* Sorumlu Yazar: Gönül TEKKURŞUN DEMİR
}

E-mail: gonultekkursun@hotmail.com 
Tekkurşun Demir, G. ve İlhan, EL. (2019). Spora Katılım Motivasyonu: Görme Engelli Sporcular Üzerine Bir Araştırma. Gaziantep Üniversitesi Spor Bilimleri Dergisi, 4(1), 157-170.

\title{
Motivation for Participation in Sports: A Research on the Visually Impaired
}

\section{Athletes}

\begin{abstract}
In general expression, visually impaired people are the persons that are affected by visual disability. Sports is one of the important factors that helps visually impaired individuals to take their places in daily life, to connect them to life by socializing, to orient themselves with motivation and to accept the idea that visual disability is not an obstacle to continue living. In this study, it was aimed to determine the motivation levels of licensed visually impaired athletes for participation in sports according to various variables. In this context, descriptive survey model from quantitative research methods was used in the research. The sample of the study consists of 80 (23 female, 57 male) licensed athletes who were 60 national and 20 non-national athletes from Turkey Sports Federation for the Visually Impaired. In the research, a personal information form prepared by the researchers and the "Scale of Motivation for Participation in Sports in Persons with Disabilities (SMPSPD)" developed by Tekkurşun, İlhan, Esentürk and Kan (2018) were used as a data collection tool. In the analysis of the data obtained in the research; frequency, arithmetic mean, standard deviation as well as t-test, Pearson Moment Correlation, Mann-Whitney $U$ and Kruskal-Wallis tests were used. In the study, it was determined that the internal motivation score means of visually impaired judoists were significantly higher than the weightlifters and their external motivation score means were significantly higher than the goalballers. There was a significantly moderate positive difference between the age of the athletes and External Motivation level. There was no significant difference according to the gender of the participants. A high level of positive difference was found between the sports history of visually impaired athletes and their Internal Motivation, External Motivation and Non-Motivation dimensions. It was concluded that the motivation visually impaired athletes for participation in sports were at a high level.

Keywords: İmpaired, Visually İmpaired, Sports, Motivation For Participation İ Sports, Motivation
\end{abstract}

\section{Giriş}

Bireyler, motorik, sosyal, duygusal ve bilişsel farklılıklarıyla toplumsal hayatın üyeleri olarak yaşamlarını sürdürürler. Bireyin yetersizlikten etkilenmesi ve bu yetersizliğin derecesine bağlı olarak hareket kısıtlılığı yada duyusal kayıpların yarattığı eksiklik onu toplumun diğer bireylerinden farklı kılabilir (Tekkurşun ve ark. 2018). Diğerlerinden farklı olma durumu, engelli olma hâli, "yeti yitimi" olarak adlandırılır.

Engelli kavramı, kişinin vücudunda duyuşsal, zihinsel ve bedensel farklılıkları belirtilerek; toplumsal veya yönetimsel tutum ve tercihleri sonucunda, yaşamın bir çok noktasında kısıtlama ve engellerle karşılaşmasıdır (WHO, 2014). Kişilerin sahip oldukları kısıtlama ve engeller "engel türleri" adı altında dörde ayrılır. Bu engel türleri zihinsel engellilik, işitme engelliliği, bedensel engellilik ve görme engelliliğidir.

Görme engelli kişiler, genel bir ifade ile görme yetersizliğinden etkilenen, görme yetisini etkin şekilde kullanamayan kişilerdir. Görme yetisini tam olarak kullanamayan bireylerin kimler olduğunu kavramsallaştıran kesin bir tanıma erişmek kolay değildir. Görme engeli; bireylerin zihinsel, sosyal gelişimlerinin ilerlemesini, öğrenme becerilerinin arttırılmasını ve kişilerin günlük aktivitelerini olumsuz etkileyen bir engeldir (Bailey ve Wning, 1994). Yaşamın bir çok noktasında görme engelinin bireylerin yaşantısına olumsuz etkilerinin azaltılması, görme engelli bireylerin 
Tekkurşun Demir, G. ve İlhan, EL. (2019). Spora Katılım Motivasyonu: Görme Engelli Sporcular Üzerine Bir Araştırma. Gaziantep Üniversitesi Spor Bilimleri Dergisi, 4(1), 157-170.

gündelik yaşam içinde yerini alması, sosyalleşerek hayata bağlanması, hedefine motivasyonla yönelmesi, görme engelliliğinin bir engel olmadığı fikrinin kabullenilmesine yardımcı olan önemli unsurlardan biri spordur.

Spor beden ve ruh sağlığının gelişmesi ile birlikte belli kurallara göre rekabet ölçüleri içinde mücadele etme, heyecan duyma, yarışma, yarışmada üstün gelme arzusunu içerir (Tamer ve Pulur, 2001; Yücel, 2004). Spor, insanın kazanmak için mücadele azmini ile kurallar içerisinde yaptığı bedensel etkinliklerdir (Aracı, 2006). Spor yapan kişinin kendisine olan güveni daha fazla, çevresi ile uyumu daha iyi, ruhsal sağlığı daha dengeli ve düzenlidir (İlhan, 2010). Hiç şüphesiz engelli bireyler de sportif faaliyetlerde etkin bir yere sahiptir. Spor, kişinin bedensel ve ruhsal açıdan sağlığını iyileştiren, sosyal çevre ile iletişimini arttıran, zihinsel ve motorik açıdan kişiyi belirli bir düzeye getiren biyolojik, pedagojik ve sosyal bir olgudur. Bu nedenle, engeli olan bireylerin sosyal uyumlarının gerçekleşme aşamasında spor bir araç olarak değerlendirilmelidir (İlhan, 2008).

Sporun normal gelişim gösteren kişiler üzerinde gösterdiği olumlu etkilerin hepsini ve hatta daha fazlasını engelli kişiler üzerinde de gözlemlemek mümkündür. Spor etkinliklerinin hepsi engelliler için toplumsal bir deneyim olmanın yanında sporun doğal ortamı içinde bulunan tüm bireyleri farklı şekillerde etkilemekte ve tüm gelişim boyutlarını desteklemektedir (Tekkurşun ve ark. 2018).

Engelli bireylerin bir çoğu düzenli olarak spora katılamamaktadır, bu da ikincil sağlık sorunlarının gelişmesi olasılığını artırabilir. Bu nedenle, spor katıımın önündeki zorluklar ve kolaylaştıııcılar hakkında bilgi kaynağına ihtiyaç vardır (Jaarsma ve ark. 2014). Tenenbaum ve Eklund (2007), engelli bireylerin spor katılımlarının önündeki en büyük sorunsalın zaman ve motivasyon eksikliği olduğunu savunmaktadırlar. Motivasyon; davranışı harekete geçiren unsur (Aydın, 2010), bireyin ortaya koyduğu çabanın yönü ve yoğunluğu (Toros, 2001), davranışın ustalık, yön, şiddet ve devamlıı̆̆ının nedeni olarak içsel ve dışsal etmenlerin varsayıma dayanarak tahmin edilmesi (Tenenbaum ve Eklund, 2007) olarak tanımlanmaktadır. Ülkemizde sağlıklı bireylerin spora katılım motivasyonlarına ilişkin yapılan pek çok araştırma (Ardahan, 2013; Demir ve Cicioğlu, 2018; Hazar, Demir ve Can, 2018; Frederick-Recascino, 2002; IIIhan ve Gencer, 2013; IIIhan 2009; Kaman, 2017; Kaplan ve Ardahan, 2013; Korkutata, 2016; Murcia, Gımeno ve Coll, 2008; Roberts, Treasure ve Conroy, 2007; Şirin ve ark., 2008) mevcuttur bunun yanında görme engelliler ve sporun ele alındığı 
Tekkurşun Demir, G. ve İlhan, EL. (2019). Spora Katılım Motivasyonu: Görme Engelli Sporcular Üzerine Bir Araştırma. Gaziantep Üniversitesi Spor Bilimleri Dergisi, 4(1), 157-170.

araştırmalara az da olsa rastlanmaktadır (Keskin, 2008; Türk, 2007; Tükel, 2015; Tekkurşun ve ark., 2018; Yılmaz, 2011).

Motivasyon kavramına, spora yönelme yada yöneltme mantığı ile bakıldığında, özellikle engelli bireyler arasında sporu yaygın hale getirmek ve bu yaygınlaştırma doğrultusunda kullanılabilecek dinamikleri belirleme gerekliliği ortaya çıkmaktadır. Bireyler spor yapmak için birçok farklı motivasyon kaynaklarına sahip olabilirler. Bu motivasyon kaynakları içsel, dışsal ve motivasyonsuzluktur. Bireyin spora katılımda huzur bulması, mutlu olması içsel motivasyon kaynağını oluştururken; ödül, ceza gibi faktörler dışsal motivasyon kaynaklarını oluşturmaktadır. Birey spora katılımda neden sonuç ilişkisini kuramadığı durumlarda motivasyonsuzluk kaynağından etkilenir. Bu bağlamda spora katılımda bireylerin motivasyon kaynaklarının ortaya konması, tüm gelişim boyutları ve bireysel başarının sağlanması açısından önemlidir. Ülkemizde engelliler sporu hem nicelik hem de nitelik olarak günden güne mesafe almaktadır. Görme engelli sporcuların neden spor branşlarına katılım gösterdiklerinin betimlenmesi bu araştırmanın çıkış noktasıdır. Bu bağlamda araştırmanın amacı; lisanslı olarak Türkiye Görme Engelliler Spor Federasyonu bünyesinde aktif olarak spor yapan 16-48 yaş aralığındaki 80 görme engelli sporcunun spora katılım motivasyon düzeylerini tespit etmek ve buna göre branş, yaş, cinsiyet, spor yapma yılı değişkenleri açısından incelemektir.

\section{Yöntem}

Bu bölümde, araştırmaya katılan bireyler, veri toplama aracı ve verilerin toplanması ile verilerin analizi için kullanılan istatistiksel yöntemlerden bahsedilmektedir. Araştırmada nicel araştırma yöntemlerinden betimsel tarama modeli kullanılmıştır.

Betimsel tarama, bir değişkene ilişkin sayısal değerlerin toplanması, betimlenmesi ve sunulmasına olanak sağlayan istatistiksel işlemlerdir (Büyüköztürk ve ark. 2014).

\section{Çalışma Grubu}

Araştırmanın çalışma grubunu Ankara ilinde Türkiye Görme Engelliler Spor Federasyonu'nda aktif olarak spor yapan görme engelli sporcular oluşturmaktadır. Buna göre araştırmaya 60 milli, 20 milli olmayan olmak üzere toplam 80 (23 kadın, 57erkek) lisanslı sporcu katılmıştır. Araştırmaya gönüllü olarak katılan katılımcılara, anket formundaki maddeler araştırmacılar tarafından okunmuş ve katılımcı tarafından uygun görülen şekilde doldurulmuştur. 


\section{Veri Toplama Aracı}

Araştırmada veri toplama aracı olarak, katılımcılar hakkında bilgi toplamak amacıyla araştırmacılar tarafından oluşturulan "Kişisel Bilgi Formu" ile Tekkurşun, İlhan, Esentürk ve Kan (2018) tarafında geliştirilen 22 maddeden oluşan "Engelli Bireylerde Spora Katılım Motivasyonu Ölçeği (ESKMÖ)” kullanılmıştır. Ölçek "İçsel Motivasyon" adı altında ilk 12, "Dışsal Motivasyon" altında 5, "Motivasyonsuzluk" adı altında son 5 maddeyi içermektedir. Motivasyonsuzluk faktörü ters maddelerden oluşmaktadır. Katımcılardan elde edilen verilere göre İçsel Motivasyon boyutunun Cronbach alfa değeri ,83; Dışsal Motivasyon boyutunun Cronbach alfa değeri ,87 ve Dışsal Motivasyon boyutunun Cronbach alfa değeri ,88 olarak hesaplanmıştır.

\section{Verilerin Analizi}

İstatistiksel analizlerden önce verilerin normalliği, eksik değerleri ve aykırı değerleri incelenmiştir. Bu bağlamda normallik veya aykırı değerler için herhangi bir değişiklik yapılması gerekmemiştir. Bu bağlamda Çarpıklık ve Basıklık (verilerin normal dağılım durumu) değerleri \pm 1 arasında olmadığı için verilere non-parametrik testler uygulanmıştır (Büyüköztürk ve ark. 2014). Verilerin analizinde; frekans, aritmetik ortalama, standart sapma; Pearson Moment Korelasyon testi, MannWhitney U Testi ve Kruskal-Wallis Testi kullanılmıştır. Anlamlılık ,05 alınmıştır.

\section{Bulgular}

Tablo 1. Görme Engelli Sporcuların Branşlarına Göre Yapılan Kruskal Wallis Testi Sonuçları

\begin{tabular}{|c|c|c|c|c|c|c|}
\hline & Branş & $\mathbf{N}$ & Sıra Ortaması & $x^{2}$ & p & $\begin{array}{c}\text { Anlaml } \\
\text { Fark }\end{array}$ \\
\hline \multirow{4}{*}{ 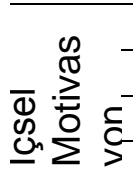 } & Judo (a) & 19 & 51,13 & \multirow{4}{*}{11,882} & \multirow{4}{*}{, $00^{*}$} & \multirow{4}{*}{$a^{*}-d$} \\
\hline & Futbol (b) & 25 & 46,16 & & & \\
\hline & Goalball (c) & 26 & 29,92 & & & \\
\hline & Halter (d) & 10 & 33,65 & & & \\
\hline \multirow{4}{*}{ 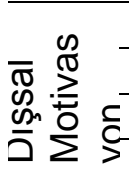 } & Judo (a) & 19 & 54,92 & \multirow{4}{*}{14,299} & \multirow{4}{*}{, $00^{*}$} & \multirow{4}{*}{$a^{*}-c$} \\
\hline & Futbol (b) & 25 & 43,14 & & & \\
\hline & Goalball @ & 26 & 29,35 & & & \\
\hline & Halter (d) & 10 & 35,50 & & & \\
\hline \multirow{4}{*}{ 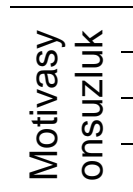 } & Judo (a) & 19 & 42,71 & \multirow{4}{*}{1,512} & \multirow{4}{*}{, 62} & \multirow{4}{*}{ - } \\
\hline & Futbol (b) & 25 & 41,78 & & & \\
\hline & Goalball @ & 26 & 40,79 & & & \\
\hline & Halter (d) & 10 & 32,35 & & & \\
\hline
\end{tabular}


Tekkurşun Demir, G. ve İlhan, EL. (2019). Spora Katılım Motivasyonu: Görme Engelli Sporcular Üzerine Bir Araştırma. Gaziantep Üniversitesi Spor Bilimleri Dergisi, 4(1), 157-170.

Tablo 1' de görme engelli sporcuların spor branşlarına göre spora katııım motivasyonlarının tespit edilmesi amacıyla yapılan Kruskal Wallis testi yer almaktadır. Katılımcıların branşlarına göre içsel motivasyon ve dışsal motivasyon boyutunda anlamlı farklılık saptanmıştır $(p<, 05)$. Lehine anlamlı farklıık gösteren gruplar * ile gösterilmiştir. Görme engelli joducuların içsel motivasyon puan ortalamalarının (sıra ort $=51,13)$ haltercilerin puan ortalamalarına (sıra ort=33,65) kıyasla anlamlı düzeyde yüksek olduğu saptanmıştır. Görme engelli judocuların dışsal motivasyon sıra ortalamalarının (sıra ort=54,92) goalballcilerden (sıra ort=43,14) anlamlı düzeyde yüksek olduğu görülmektedir.

Tablo 2. Görme Engelli Sporcuların ESKMÖ Ortalamaları

\begin{tabular}{|c|c|c|c|c|}
\hline 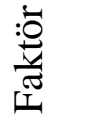 & 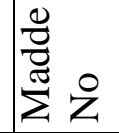 & ESKMÖ Maddeleri & $\overline{\boldsymbol{x}}$ & SS \\
\hline \multirow{12}{*}{ 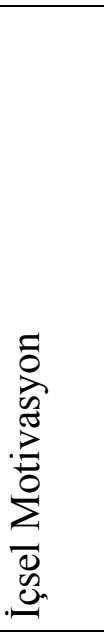 } & 1 & Spor, yetersizliklerimi en aza indirir. & 3,96 & 1,18 \\
\hline & 2 & Spor özgür hissettirir. & 4,57 & 61 \\
\hline & 3 & Spor zorluklarla mücadele edebilme özelliği kazandırır. & 4,52 & 65 \\
\hline & 4 & Spor kendi sınırımı bilmemi sağlar. & 4,17 & 1,05 \\
\hline & 5 & Spor sayesinde engelimle başa çıkabilirim. & 4,35 & ,95 \\
\hline & 6 & Sporda kazanmak bana haz verir. & 4,68 & 49 \\
\hline & 7 & Yeteneklerimi keşfetmek bana mutluluk verir. & 4,66 & ,59 \\
\hline & 8 & Spor kişisel gelişimimi arttırır. & 4,58 & 63 \\
\hline & 9 & $\begin{array}{l}\text { Sporun fiziksel gelişimime olumlu etkisi olduğunu } \\
\text { düșünürüm. }\end{array}$ & 4,76 & ,60 \\
\hline & 10 & Spor dayanıklılı̆̆ımı arttırır. & 4,72 & 44 \\
\hline & 11 & Spor kas kütlemi arttırır. & 4,53 & ,52 \\
\hline & 12 & Spor yapınca kendimi iyi hissederim. & 4,60 &, 58 \\
\hline \multirow{5}{*}{ 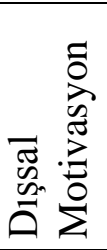 } & 13 & Engelli arkadaşlarıma örnek olmak için spor yaparım. & 3,80 & 1,15 \\
\hline & 14 & Sporun bana statü kazandırdığına inanırım. & 4,18 & ,88 \\
\hline & 15 & Medyadaki sportif başarı hikâyelerine özenirim. & 3,81 & 1,12 \\
\hline & 16 & Spor benim için sosyal güvence aracıdır. & 3,28 & 1,39 \\
\hline & 17 & Yeteneklerimi başkalarına göstermek hoşuma gider. & 3,50 & 1,41 \\
\hline \multirow{5}{*}{ 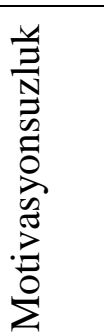 } & 18 & $\begin{array}{l}\text { Spora zaman ve efor harciyorum ama buna değer mi } \\
\text { bilmiyorum. }\end{array}$ & 3,83 & 1,24 \\
\hline & 19 & Sporun bana ne kazandırdığından emin değilim. & 4,25 & 81 \\
\hline & 20 & Sporcuyum ama spor yapmak bana göre değil. & 4,46 & 85 \\
\hline & 21 & Sporcuyum ama elimde olsa spor yapmam. & 4,31 & ,98 \\
\hline & 22 & $\begin{array}{l}\text { Branşımda ne kadar ilerleyebileceğim ile ilgili bir fikrim } \\
\text { yok. }\end{array}$ & 3,88 & 1,21 \\
\hline
\end{tabular}

Tablo 2'de ESKMÖ'nün boyutları bakımından veri toplama aracındaki maddeler göz önüne alındığında, tabloda öne çıkan içsel motivasyon boyutu maddelerine göre görme engelli sporcuların "Sporun fiziksel gelişimime olumlu etkisi 
olduğunu düşünürüm." maddesi puan ortalamasının $(\overline{\boldsymbol{x}}=4,76)$ diğer madde ortalamalarından yüksek olduğu belirlenmiştir. Fiziksel gelişim etkisinin yanında diğer içsel motivasyon maddeleri göz önüne alındığında, fizyolojik bir etki olarak "Spor dayanıklıı̆ımı arttıır" maddesi $(\bar{x}=4,72)$ ortalama ile ikinci sırada yer almıştır. Dışsal motivasyon boyutu maddelerine göre görme engelli sporcuların "Sporun bana statü kazandırdığına inanırım" maddesi puan ortalamasının $(\bar{x}=4,18)$ diğer madde ortalamalarından yüksek olduğu belirlenmiştir. Bunun yanı sıra diğer dışsal motivasyon maddeleri göz önüne alındığında, "Medyadaki sportif başarı hikâyelerine özenirim" maddesi $(\bar{x}=4,72)$ ortalama ile ikinci sırada yer almıştır.

Tablo 3. Görme Engelli Sporcuların Yaşı ile ESKMÖ Arasındaki Illişki

\begin{tabular}{lccc}
\hline Değişken & İçsel Motivasyon & $\begin{array}{c}\text { Disssal } \\
\text { Motivasyon }\end{array}$ & Motivasyonsuzluk \\
\hline Yaş &, $398^{\star \star}$ &, 112 &,- 09 \\
\hline $\mathrm{p}^{\star}<, 05$ & & &
\end{tabular}

Tablo 3'te Görme engelli sporcuların yaşı ile ESKMÖ arasındaki ilişkinin tespit edilmesi amacıyla yapılan Pearson Moment Korelasyon Testi yer almaktadır. Yapılan analiz sonucunda, yaş değişkeni ile ESKMÖ faktörleri arasında anlamlı farklılık tespit edilmiştir $(p<, 05)$. Buna göre yaş değişkeni ile İçsel Motivasyon arasında pozitif yönde orta düzeyde anlamlı farklılık tespit edilmiştir $(r=, 398 ; p<, 05)$.

Tablo 4. Görme Engelli Sporcuların Spora Katılım Motivasyonunun Cinsiyete Göre İncelenmesi

\begin{tabular}{|c|c|c|c|c|c|c|c|}
\hline Değişken & Cinsiyet & $\mathbf{N}$ & $\begin{array}{c}\text { Sıra } \\
\text { ortalaması }\end{array}$ & $\begin{array}{c}\text { Sıra } \\
\text { toplamı }\end{array}$ & $\begin{array}{c}\text { Mann } \\
\text { Whitney } \\
U\end{array}$ & $\mathbf{Z}$ & p \\
\hline İçsel Motivasyon & $\begin{array}{l}\text { Kadın } \\
\text { Erkek }\end{array}$ & $\begin{array}{c}58 \\
143\end{array}$ & $\begin{array}{l}100,41 \\
101,24\end{array}$ & $\begin{array}{c}5823,50 \\
14477,50\end{array}$ & 4112,500 &,- 926 & ,92 \\
\hline Dışsal Motivasyon & $\begin{array}{l}\text { Kadın } \\
\text { Erkek }\end{array}$ & \begin{tabular}{|c|}
58 \\
143 \\
\end{tabular} & $\begin{array}{c}106,89 \\
98,61 \\
\end{array}$ & $\begin{array}{c}6199,50 \\
14101,50\end{array}$ & 3805,500 &,- 916 & ,36 \\
\hline Motivasyonsuzluk & $\begin{array}{l}\text { Kadın } \\
\text { Erkek }\end{array}$ & $\begin{array}{c}58 \\
143\end{array}$ & $\begin{array}{l}42,20 \\
39,82\end{array}$ & $\begin{array}{c}970,50 \\
2269,50\end{array}$ & 616,500 &,- 419 & ,67 \\
\hline
\end{tabular}

$\mathrm{p}^{\star<}<, 05$

Tablo 4'te de görüldüğü gibi katııımcıların cinsiyet değişkeni ile engellilerin spora katılım motivasyonu arasındaki ilişki Mann Withney $U$ testi ile incelenmiştir. Yapılan analiz sonucunda görme engelli kadın ve erkek sporcuların spora katıım motivasyonu alt boyutlarında anlamlı farklılık tespit edilmemiştir $(p>, 05)$. 
Tekkurşun Demir, G. ve İlhan, EL. (2019). Spora Katılım Motivasyonu: Görme Engelli Sporcular Üzerine Bir Araştırma. Gaziantep Üniversitesi Spor Bilimleri Dergisi, 4(1), 157-170.

Tablo 5. Görme Engelli Sporcuların Spor Yaşı İle Spora Katılım Motivasyonu Arasındaki İlişki

\begin{tabular}{lccc}
\hline Değişken & İçsel Motivasyon & Dışsal Motivasyon & Motivasyonsuzluk \\
\hline Yaş &, $565^{\star \star}$ & $455^{\star \star}$ & $410^{\star \star}$ \\
\hline $\mathrm{p}^{\star<, 05}$ & Tablo 5 'te & Görme engelli & sporcularının ESKMÖ ile spor yaşı değişkeni
\end{tabular}
arasında yapılan Pearson Moment Korelasyon Testine ait bulgular yer almaktadır. Yapılan analiz sonucunda, spor yaşı ile ESKMÖ faktörleri arasında anlamlı farklılık tespit edilmiştir $(p<, 05)$. Buna göre spor yaşı değişkeni ile İçsel Motivasyon faktörü arasında pozitif yönde yüksek düzeyde anlamlı farklılık tespit edilmiştir ( $r=, 565$; $p<, 05)$. Görme engelli sporcuların spor yaşı ile Dışsal Motivasyon faktörü arasında pozitif yönde yüksek düzeyde anlamlı farklılık saptanmıştır $(r=, 455 ; p<, 05)$. Katılımcıların spor yaşı ile Motivasyonsuzluk faktörü arasında pozitif yönde yüksek düzeyde anlamlı farklılık saptanmıştır.

\section{Tartışma}

Araştırmada lisanslı olarak Türkiye Görme Engelliler Spor Federasyonu bünyesinde aktif olarak spor yapan 16-48 yaş aralığındaki 80 görme engelli sporcunun spora katılım motivasyon düzeylerini tespit etmek amaçlanmıştır. Bu bağlamda araştırmaya görme engelli judo, futbol, goalball, halter branşlarında sporcular katılmıştır.

Engelliler sporlarının yaygınlaştırma hareketine hizmet eden farklı araştırmaların (Demir ve ark. 2017; Ergun, 2011; Filazoğlu ve ark. 2015; Güvendi ve İlhan, 2017; İlhan ve Suveren, 2009; Kabasakal, 2007; Namlı, 2012; Namlı ve Suveren, 2017; Tekkurşun ve ark. 2018; Yarımkaya ve ark. 2017; Yılmaz ve ark, 2014) yanı sıra özellikle görme engelli bireylerin spora yönelimin nedenlerine ilişkin ip uçlarının belirlemesine doğrudan hizmet etme amacı taşıyan bu araştırmada motivasyonel faktörler, bazı değişkenler (spor branşı, cinsiyet ve sporculuk yaşı) bakımdan ele alınmıştır.

Araştırmada görme engelli sporcuların spor branşlarına göre içsel motivasyon ve dışsal motivasyon boyutunda anlamlı farklılık saptanmıştır. Buna göre, görme engelli joducuların içsel motivasyon puan puanlarının haltercilere kıyasla anlamlı düzeyde yüksek olduğu saptanmıştır. Buna göre judocuların spora katılımda daha 
Tekkurşun Demir, G. ve İlhan, EL. (2019). Spora Katılım Motivasyonu: Görme Engelli Sporcular Üzerine Bir Araştırma. Gaziantep Üniversitesi Spor Bilimleri Dergisi, 4(1), 157-170.

fazla duyguları ve iç sezgileri ile hareket ettiği, daha fazla heyecan, mutluluk gibi duyuşsal özellikleri ile spora katıldığı söylenebilir. Görme engelli judocuların dışsal motivasyon puan ortalamalarının goalballcilerden anlamlı düzeyde yüksek olduğu tespit edilmiştir. Buna neden olarak, judocuların spora katılımda daha fazla çevresel faktörlerden beslendiği, ödül, alkış, arkadaş ve antrenör ilişkilerinden daha fazla etkilendiği düşünülebilir. Tüm bu farklılıklar incelendiğinde judo yapan görme engelli sporcuların vücutlarındaki fiziksel gelişim ile hem içsel hem de dışsal olarak motivasyonunu beslediği düşünülebilir. Literatürde, judo yapan görme engelli sporcular üzerinde yapılan araştırmalarda judo temel eğitiminin, engelli öğrencilerin fiziksel gelişimleri üzerinde olumlu etkileri kanıtlanmıştır. (Franchini, Takito, Cavinato, Matheus, Bertuzzi ve Vieira, 2005; Yılmaz, Tatar, Ateş ve Tiryaki, 2013).

Katıım motivasyonu, boyutlar ve maddeler bazında alındığında, görme engelli sporcularda içsel motivasyon boyutunda öne çıkan "Sporun fiziksel gelişimime olumlu etkisi olduğunu düşünürüm" maddesinin araştırma grubunda fiziksel gelişim düşüncesinin en önemli katılım motivasyonu olduğu söylenebilir. Fiziksel gelişim etkisinin yanında diğer içsel motivasyon maddeleri göz önüne alındığında, fizyolojik bir etki olarak "Spor dayanıklıı̆ı̆ımı arttırı" maddesinin de ikinci sırada bir motivasyon nedeni olduğu belirlenmiştir. Nitekim toplumsal ve genel bir yaklaşımla, sporun tüm gelişim boyutlarını desteklemesinin yanı sıra özellikle fiziksel gelişim ile ilişkilendirildiği araştırmalar mevcuttur (Demir ve ark. 2017). Dışsal motivasyon boyutu maddelerine göre görme engelli sporcuların "Sporun bana statü kazandırdığına inanııı" maddesi üzerinde yoğunlaştıklarını, bunun yanı sıra diğer dışsal motivasyon maddeleri göz önüne alındığında, "Medyadaki sportif başarı hikâyelerine özenirim" maddesinin ikinci sırada yer aldığı belirlenmiştir.

Görme engelli sporcuların yaşı ile spora katılım motivasyonu düzeyi incelendiğinde, içsel motivasyon boyutu ile yaş arasında pozitif yönde orta düzeyde anlamlı farklılık tespit edilmiştir. Bu bağlamda görme engelli sporcuların yaşı arttıkça spora katılımda bireysel istek, heyecan, hırs, mutluluk gibi içsel motivasyon kaynaklarının arttığı söylenebilir. Ayrıca sporcuların spor yaşı arttıkça spora katııı motivasyonunda da ciddi bir artış olduğu, bunun da benlik saygısını artırdığı söylenebilir. Oysa engelli olmayan bireylerde, yaş ve katıtım motivasyonu ilişkisini ele alan bazı araştırmalarda, yaşa bağlı olarak iç motivasyonun aza azalıp, dışsal nedenlerin ön plana geçebileceği belirtilmektedir. Benzer olarak sporcularda zamanla statü ve ödülün, iç motivasyonu bastıran unsurlar olabileceği savunulmaktadır (Weiss 
ve Chaumeton, 1992). Çeker ve ark. (2013) spora katılımın yaş faktörüne bağlı olarak azaldığını belirtmektedirler. Oysa görme engelli sporcuların sporculuk süreçlerinde içsel ve dışsal motivasyonel kaynaklarını sürekli olarak besledikleri, bu araştırmanın bulguları ile ortaya konulmuştur.

Araştırmada katılımcıların cinsiyet değişkeni incelendiğinde, görme engelli kadın ve erkek sporcuların spora katılım motivasyonu alt boyutlarında anlamlı farklılık tespit edilmemiştir. Buna neden olarak kadın ve erkeklerin benzer branşları eşit rol paylaşımı ile yapmaları, benzer düzeyde spora katılım motivasyonlarına sahip olmaları gösterilebilir. Araştırmanın son bulgusunda görme engelli sporcularının ESKMÖ ile spor yaşı değişkeni arasında anlamlı farklılık tespit edilmiştir. Buna göre sporcuların spor yaşı değişkeni ile İçsel Motivasyon faktörü arasında pozitif yönde yüksek düzeyde anlamlı farklılık tespit edilmiştir. Sporcuların spor yaşı arttıkça spora katılımda keyif alma, arzu ve istek gibi içsel motivasyon kaynaklarının ciddi bir şekilde arttırdığı söylenebilir.

Görme engelli sporcuların spor yaşı ile Dışsal Motivasyon faktörü arasında pozitif yönde yüksek düzeyde anlamlı farklılık saptanmıştır. Bu bağlamda görme engelli katılımcıların spor yaşına göre spora katılım motivasyonlarının dış etkilerden, popüler olmak, kendini çevreye ispatlamak gibi dışsal motivasyon kaynaklarından oldukça etkilendiği ve spora katılımla birlikte arttığı söylenebilir. Katılımcıların spor yaşı ile Motivasyonsuzluk faktörü arasında pozitif yönde yüksek düzeyde anlamlı farklılık saptanmıştır. Görme engelli sporcuların spor yaşı arttıkça spora neden katıldıkları ve sonuçları arasındaki bağlantıyı kurma düzeylerinin de arttığı söylenebilir.

Sonuç olarak görme engelli sporcuların spora katılım motivasyonlarının yüksek olduğu sonucuna varılmıştır. İç motivasyonel yönelim faktörleri bakımından fiziksel ve fizyolojik gelişim güdüsünün ön plana çıktığı. Dışsal güdü kaynakları arasında ise statü elde etmenin ve başarılı olma duygusunun harekete geçirici en temel unsurlar olduğu belirlenmiştir. Spor, engellilerin kendilerini ifade edebilecekleri tüm gelişimlerini destekleyen bir araçtır. Toplumsallaşma yolunda tüm engelli bireyler arasında sporun yaygınlaştırma hareketine hizmet edeceğini düşündüğümüz ve kişileri spora yönelten nedenlerin betimlenmeye çalışıldığı bu araştırmanın ardından farklı yaş gruplarında ve farklı engel türlerinde de yapılacak olan yeni çalışmaların, spora katılım ve bireyleri bu etkin mekanizmaya teşvik edecek tedbirlerin alınması bakımından değerli etkiler yaratabileceği düşünülmektedir. 


\section{Kaynaklar}

Ardahan, F. (2013). Bireyleri Rekreatif Spor Etkinliklerine Motive Eden Faktörlerin Remm Ölçeğini Kullanarak Çeşitli Demografik Değişkenlere Göre İncelenmesi: Antalya Örneği. Pamukkale Journal Of Sport Sciences, 4(2).

Aracı, H. (2006). Öğretmen ve Öğrenciler İçin Okullarda Beden Eğitimi, Geliştirilmiş 6. Baskı, Ankara: Nobel Yayın Dağıtım.

Aydın, F. (2010). Ortaöğretim öğrencilerinin coğrafya dersinde güdülenmelerine olumsuz etki eden faktörlere ilişkin görüşleri. Balıkesir Üniversitesi Sosyal Bilimler Enstitüsü Dergisi, 13(24). 31-43.

Bailey, B. R. ve Wning, J. D. (1994). Using visual accents to enhance attending to communication symbols for students with severe multiple disabilities. Re:View, 26(3), 101- 118.

Büyüköztürk, Ş., Çakmak, E. K., Akgün, Ö. E., Karadeniz, Ş. ve Demirel, F. (2014). Bilimsel araştırma yöntemleri. (18. Baskı) Ankara: Pegem Akademi.

Demir, G. T., İlhan, E. L., Cicioğlu, H. I., \& Serkan, K. (2017). Headmaster And Teacher Opınıons For Specıal Olympıcs Young Athletes Program. Ovidius University Annals, Series Physical Education and Sport/Science, Movement and Health, 17(2), 302-311.

Demir, G. T., \& Cicioğlu, H. İ. (2018). Motivation Scale For Participation In Physical Activity (MSPPA): A study of validity and reliability Fiziksel Aktiviteye Katılım Motivasyonu Ölçeği (FAKMÖ): Geçerlik ve güvenirlik çalışması. Journal of Human Sciences, 15(4), 2479-2492.

Ergun, N. (2011). Bedensel Engellilerde Sportif Aktiviteler ve Klasifikasyon. Uluslararası Katılımlı Engellilerde Beden Eğitim ve Spor Kongresi Kongre Kitabı, 42-47.

Filazoğlu-Çokluk, G. Kırımoğlu, H., Öz, AŞ, İlhan EL, (2015). International Journal of Science Culture and Sport, (IntJSCS), 11 (3), 52-58

Frederick-Recascino, C. M. (2002). Self-determination theory and participation motivation research in the sport and exercise domain. Handbook of selfdetermination research, 277.

Franchini E., Takito M. Y., Cavinato C. C., Matheus L ., Bertuzzi R. C. M., Vieira D. E. B. (2005). Relationship Between Morphological, Physiological and Technical Variables in High Level College Judo Players 2005 World Judo Research Symposium, Ciro, Egypt. 2005 
Gürsel, O. (2012). Görme yetersizliği olan öğrenciler. İ.H. Diken (Ed.). Özel eğitime gereksinimi olan öğrenciler ve özel eğitim içinde (s. 217-249). Ankara: Pegem Akademi.

Güvendi, B., ve İlhan, E. L. (2017). Effects of adapted physical activity applied on intellectual disability students toward level of emotional adjustment, selfmanagingand the socialization: Parent and teacher interactive research. Journal of Human Sciences, 14(4), 3879-3894.

Hazar, Z., Demir, G. T., ve Can, B. (2018). Lise Öğrencilerinin Spora Katılım Güdülerinin Farklı Değişkenler Açısından İncelenmesi. Spormetre Beden Eğitimi ve Spor Bilimleri Dergisi, 16(4), 225-235.

Kabasakal K. (2007). Zihinsel Engellilik, Zihinsel, Ruhsal, Duygusal Engellilik, Lokomotif Medya, Ünimat Ofset Matbaası, Konya.

İlhan, L. (2008). Eğitilebilir Zihinsel Engelli Çocuklarda Beden Eğitimi ve Sporun Sosyalleşme Düzeylerine Etkisi. Kastamonu Eğitim Dergisi, 16(1), 315-324.

İlhan, L. (2009). Voleybolda Servis Becerisi Öğretimine Motivasyonel Bir Yaklaşım. Beden Eğitimi ve Spor Bilimleri Dergisi, 3(3), 196-203.

İlhan, L., ve Suveren, S. (2009). Zihinsel Engelli Çocuğu Olan Anne-Babaların Çocuklarının Özel Eğitimleri Sürecinde Beden Eğitimi Ve Spor Etkinliklerine Yaklaşımlarının Değerlendirilmesi. Niğde Üniversitesi Beden Eğitimi Ve Spor Bilimleri Dergisi, 3(1), 38-48.

İlhan, E. L. (2010). “Hareketsiz Yaşamlar Kültürü ve Beraberinde Getirdikleri”. Milli Prodüktivite Merkezi Verimlilik Dergisi, 3,195-210

İlhan, L., ve Gencer, E. (2013). Liselerarası Badminton Müsabakalarına Katılan Sporcu-Öğrencilerin Spora Katılım Motivasyonlarının Belirlenmesi. Gazi Beden Eğitimi ve Spor Bilimleri Dergisi, 18(1-4), 1-6.

Jaarsma, A., Dijkstra, P. U., Geertzen, J. H. B., ve Dekker, R. (2014). Barriers to and facilitators of sports participation for people with physical disabilities: A systematic review. Scandinavian journal of medicine ve science in sports, 24(6), 871-881.

Kaman, M. B., Gündüz, N., ve Gevat, C.( 2017). Tenis Sporcularının Spora Katılım Motivasyonlarının İncelenmesi.Spormetre, 15 (2), 65-72

Kaplan, A., ve Ardahan, F. (2013). Doğa Sporları Yapan Bireylerin Profilleri, Doğa Sporu Yapma Nedenleri ve Elde Ettikleri Faydalar: Antalya Örneği. Karadeniz Sosyal Bilimler Dergisi, 5(8), 93-114. 
Keskin, S. (2008). 18-30 Yaş arası spor yapan görme engelli bireyler ile 18-30 yaş arası spor yapan gençlik ve spor genel müdürlüğü personellerinin işitsel basit reaksiyon zamanlarının karşılaştırıması. Sağık Bilimleri Enstitüsü, Beden Eğitimi ve Spor Anabilim Dalı, Yüksek Lisans Tezi, Gazi Üniversitesi, Ankara.

Korkutata, A. (2016). Participation Motivation In Sport: A Study On Taekwondo Athletes. Turkish Journal Of Sport And Exercise, 18(3), 47-55.

Murcia, J. A. M., Gimeno, E. C., Coll, D. G. C. (2008). Relationships among goal orientations, motivational climate and flow in adolescent athletes: Differences by gender. The Spanish Journal of Psychology, 11: 1, 181-191.

Namlı, S. (2012). Spor yapan ve yapmayan otistik engelli bireylerin davranış ve motor performanslarının karşılaştırııması. Yayınlanmamış yüksek lisans tezi, Sakarya Üniversitesi, Eğitim Bilimleri Enstitüsü, Sakarya.

Namlı, S. ve Suveren, S. (2017). Beden Eğitimi ve Spor Programlarında Okuyan Engelli Öğrencilerin Bölümlerine Uyumlarını Tespit Etmek Amacıyla Ölçek Geliştirme Çalışması. Beden Eğitimi ve Spor Bilimleri Dergisi, 11(3).

Roberts, G. C., Treasure, D. C., Conroy, D. E. (2007). Understanding the dynamics of motivation in sport and physical activity: An achievement goal interpretation. In G. Tenenbaum \& R. C. Eklund (Ed.), Handbook of Sport Psychology, Third Edition, John Wiley \& Sons, p. 3-10

Şirin, E. F., Çağlayan, H. S., Çetin, M. Ç. ve A., İnce (2008). Spor Yapan Lise Öğrencilerinin Spora Katılım Motivasyonlarına Etki Eden Faktörlerin Belirlenmesi. Beden Eğitimi ve Spor Bilimleri Dergisi, 2(2).

Tamer, K., ve Pulur, A. (2001). Beden Eğitimi ve Sporda Öğretim Yöntemleri. Ankara: Koza.

Tekkurşun, D. G., İlhan, E. L., Esentürk, O. K., \& Adnan, K. A. N. (2018). Engelli Bireylerde Spora Katıım Motivasyon Ölçeği (Eskmö): Geçerlik Ve Güvenirlik çalışması. Spormetre Beden Eğitimi ve Spor Bilimleri Dergisi, 16(1), 95-106.

Tenenbaum G, Eklund R.C. (2007). Exercise adherence. In: Tenenbaum G, Eklund RC, eds. Handbook of sport psychology. Hoboken, NJ: John Wiley ve Sons, Inc., 2007: 516-518.

Toros, Z. (2001). Elit Sporcuların Güdüsel Yönelimleri: Voleybolcular Üzerine Bir Araştırma. Yüksek Lisans Tezi. Mersin Üniversitesi. Sağlık Bilimleri Enstitüsü. 
Tekkurşun Demir, G. ve İlhan, EL. (2019). Spora Katılım Motivasyonu: Görme Engelli Sporcular Üzerine Bir Araştırma. Gaziantep Üniversitesi Spor Bilimleri Dergisi, 4(1), 157-170.

Tükel, Y. (2015). Görme engelli judocuların denge performanslarının incelenmesi, Yayınlanmış Doktora Tezi, Selçuk Üniversitesi Sağlık Bilimleri Enstitüsü, Konya.

Türk, E. (2007). Spor takımlarına katılan ve katılmayan görme engelli öğrencilerin benlik saygılarının değerlendirilmesi. Çukurova Üniversitesi Sosyal Bilimler Enstitüsü, Mersin

Who (2014). Management of Substance Abuse Unit. Global status report on alcohol and health, World Health Organization.

Yarımkaya E., İlhan E., L., Karasu N. (2017). Akran Aracılı Uyarlanmış Fiziksel Aktivitelere Katılan Otizm Spektrum Bozukluğu Olan Bir Bireyin İletişim Becerilerindeki Değişimlerin İncelenmesi. Ankara Üniversitesi Eğitim Bilimleri Fakültesil Özel Eğitim Dergisi,18(2), 225-252.,Doi:10.21565/ ozelegitimdergisi.319423.

Yılmaz, S., Tatar, Y., Ateş, O. ve Tiryaki, E. (2013). Judo Sporunun Görme Engelli Öğrenciler Üzerine Etkisinin Bazı Parametreler Açısından İncelenmesi, İ.Ü. Spor Bilimleri Dergisi, 11(3), 173.176.

Yılmaz, S. (2011). Judo sporunun görme engelli öğrenciler üzerine etkisinin bazı parametreler açısından incelenmesi. Spor Bilimleri Dergisi, 3.

Yılmaz, A., Şentürk, U., ve Ramazanoğlu, F. (2014). Bedensel Engellilerde Spor Konulu Araştırmaların İçerik Analizi. Spor Yönetimi ve Bilgi Teknolojileri, 9(12).

Yücel, M. (2004). Gelişim ve öğrenmenin spor kültürünün oluşmasına etkisi. Doğu Anadolu Bölgesi Araştırmaları, 100-108. 